\title{
Community-Led Local Development (CLLD)- A Tool for Implementing Regional Development Policies
}

\author{
Alina Florentina SARACU ${ }^{\star}$, Nicolae Viorel TRIF ${ }^{\star \star}$
}

\begin{tabular}{l}
\hline \multicolumn{1}{c}{ A R T I C L E I N F O } \\
\hline Article history: \\
Accepted December 2019 \\
Available online December 2019 \\
\hline JEL Classification \\
F63, I 25, 018, R58 \\
Keywords: \\
Economic development, local \\
development, development \\
strategies, Local Action Groups \\
\hline
\end{tabular}

\begin{abstract}
A B S T R A C T
In the current programming period of the EU Cohesion Policy, 2014-2020, two instruments have been introduced to implement territorial strategies based on economic and social cohesion: Community-led Local Development (CLLD) and Integrated Territorial Investments (ITI). These refer to all the funds covered by the Common Strategic Framework (European Regional Development Fund, European Social Fund, European Agricultural Fund for Regional Development, European Fisheries Fund and Cohesion Fund).
\end{abstract}

(C) 2019 EAI. All rights reserved.

\section{Introduction}

The Community-led Local Development (CLLD) is a specific tool for sub-regional use and has the capacity to mobilize and involve local communities and organizations so that they can contribute to achieve the goals of the Europe 2020 Strategy for Smart, Sustainable and Inclusive Growth , the stimulation of territorial cohesion and the achievement of the policy objectives. CLLD is complementary to other forms of local development support and can be associated with sectoral or integrated interventions established at national or regional level.

It is based on the LEADER experience of community-led local development established since the early 1990s, which has been an effective tool in providing development policies. This instrument is based on a bottom-up approach aimed at strengthening the synergies between local actors, both public and private, and matching the specific needs of the local area. This type of actions, based on the experience of the LEADER Initiative, has benefited from the EU support permanently since 1991 and has become an increasingly important element of rural development policy and since 2007 also of fisheries policy. The community-led local development has been designed to help rural actors analyze the potential of their local area, and has proven to be an effective tool for implementing development policies.

This bottom-up approach involves the formation of Local Action Groups (LAGs) consisting of representatives of the local socio-economic interests from the public and private sectors, the area of interest being represented by the surface of the administrative-territorial units contained in the LAG. Local Action Groups develop and implement integrated and multisectorial local development strategies consistent with the programs from which they receive support. [11]

\section{Territorial instruments of cohesion policy}

The Committee of the Regions also "sees the CLLD as a key-instrument for the harmonious development of urban and rural areas, enhancing the capacity to develop relations with surrounding periurban and rural areas".

The main goals pursued for simplifying and extending the use of CLLD as a development tool are [8], [13]:

$>$ encouraging local communities to develop "bottom-up" integrated approaches in circumstances where it is necessary to respond to territorial and local challenges requiring structural changes;

$>$ enhancing the capacity of the community to stimulate innovation (including social innovation), entrepreneurship and ability to change, by encouraging the development and discovery of untapped potential in communities and territories;

$>$ promoting community ownership by increasing community participation and enhancing the sense of involvement and ownership that can enhance the effectiveness of the EU policies; 
$>$ assisting multilevel governance by providing a way to fully participate in shaping the implementation of EU targets in all the domains for local communities.

Community-led local development (CLLD) includes [6]:

> "bottom-up" actions - development measures are proposed by the community itself, following a structured dialogue between the local public administration, citizens and the local business environment;

$>$ participation and consultation - all local actors have the opportunity to express their opinion on the development of their community. In all actions, the partnership between civil society, the public sector and the business environment is strongly encoraged ;

$>$ an integrated approach - it concerns community-related issues "as a whole", rather than measures related to a particular sector only (eg education, social, environmental, economic, etc.);

$>$ local involvement for quick results - the measures are implemented with local resources and initiative, within a maximum of 3-6 month period, through the direct involvement of those who want to contribute to the development of their community.

Among the advantages of CLLD we can mention[1]:

$>$ encouraging local level involvement (stimulating a bottom-up approach) and strengthening ownership at local level;

$>$ increasing the administrative capacity of local communities and stimulating innovation;

$>$ the actions under the CLLD benefit from a 10\% increase in the ERDF and / or ESF co-financing rate (ex 85\% instead of 75\%);

$>$ the possibility to coordinate the contribution of different funds, including national ones.

According to the legislative package proposed by the European Commission, Local Action Groups should have development strategies approved by December 31, 2015, so that the 2016-2020 period can be dedicated to implementing the strategies, under the mandatory monitoring of Local Action Groups. This term is, however, negotiated at European level and at present. Strategies need to be selected by a joint committee set up by the Managing Authorities involved, who will need to ensure that multi-funded strategies receive coordinated funding for the whole strategy.

The legislative package also proposes to maintain the allocation of at least $5 \%$ of the EAFRD for each Member State for community-led local development actions. It should be noted that according to the legislative proposal the CLLD refers to all funds covered by the Common Strategic Framework (ERDF, EAFRD, ESF, European Fisheries Fund and Maritime Affairs and Cohesion Fund), but its application is only mandatory for the EAFRD. It should also be noted that Member States must specify in the Partnership Agreement their intentions to support CLLD and indicate the programs and areas in which this instrument can be used.

The European Council of Municipalities and Regions (CEMR) is the largest organization of local and regional authorities in Europe, comprising as members more than 50 national associations of municipalities and regions from 41 European countries, associations that together represent about 150,000 local and regional authorities. The objectives pursued by CEMR are to influence European legislation on behalf of local and regional authorities and to provide a platform for exchange between member associations and officials and experts. CEMR considers the European Institutions' adoption of Integrated Territorial Development Instruments (CLLD, ITI) to be a breakthrough because they allow the funds to address local approaches and address territorial challenges such as poverty and social exclusion. Local development responds to a resultsoriented approach to mitigate territorial challenges as it will allow governments and local authorities to play an active role in implementing EU policy goals, in particular the Europe 2020 Strategy. At present, countries such as the Netherlands (ITI) and Finland (ITI Intercity, CLLD) use these tools and support other countries to work with CEMR members to adopt similar innovative approaches able to meet the development needs. [5] [15]

\section{Local development under the responsibility of the community}

As part of local development, the local population takes control and forms a local partnership that develops and implements an integrated development strategy. The strategy is so designed as to harness the social, environmental, and economic strengths of the community rather than offset the problems it faces. To this end, the partnership benefits from long-term funding and has the power to decide on how the funds are spent.

The application of the CLLD-based principles has spread over the past twenty years from a small group of 200 LEADER pilot projects to approximately 2,600 partnerships (both LEADER and Axis 4 of the European Fisheries Fund - EFF) covering almost every corner of rural Europe and much of the coastal area. The total public and private investment supported by such partnerships also increased to around EUR 8.6 billion over the period 2007-2013, mainly supporting a wide range of small projects, thousands of businesses and jobs and significant improvements to local and environmental services. Outside Europe, the World Bank also supports projects using a very similar Community Driven Development (CDD) methodology in 94 countries, with a total investment estimated at around $\$ 30$ billion. 
In many Member States, the situation faced by local communities at the beginning of the 2014-2020 programming period differs greatly from the one in the last two programming periods. Faced with the severity of the economic crisis, many existing local partnerships are forced to identify additional sources of funding just to continue their activities or survive. However, given the increasing social, environmental and economic difficulties, the continuation of activities as so far is no longer a long-term viable option for many local communities.

Local development partnerships placed under the responsibility of the community also face a completely different context of governance than the original one. Many of the partnerships, initially small and relatively free pilot community initiatives, have been extended to rural areas and extensive coastal regions. This has imposed considerable additional responsibility and burdens on the administrative and auditing procedures. At the same time, current top-down service delivery models are also being questioned and there is growing interest in more participatory, responsive and innovative ways to respond to the social needs, which are similar to the approach proposed by CLLD.

Compared to rural areas (EAFRD), where CLLD is implemented through the LEADER approach and fisheries areas (FEPA), where a specific Union priority is devoted to community-led local development strategies (local action groups in the fisheries sector), the Social Inclusion CLLD is only included in a limited number of partnership agreements that the Member States have concluded with the Commission. However, social inclusion can also play an important role as an integrated horizontal approach in CLLD from rural, coastal or urban areas. Social inclusion can also play a role in continuity when organizations and associations in CLLD areas require funding directly through the ESF within the priorities of the main ESF programs.

There are strong arguments that social inclusion must be a horizontal objective in all types of CLLD areas. The existing CLLD partnerships in rural and coastal areas, which in the past mainly focused on opportunities, could do more to foster social inclusion in the areas where they work. Local action groups involved in CLLD are often driven by active members of the local community and may sometimes ignore the less visible parts of the community. Integrating social inclusion into local strategies can improve the balance of these strategies and enable them to better respond to local needs.

One of the key principles of the LEADER method applicable at CLLD-s level is the innovative approach that supports innovation actions, mainly by creating products, processes, markets and organizations, in other words providing local action groups an as high as possible room for maneuver. With this in mind, there are many examples of development of local strategies and local employment initiatives in general programs, community initiatives and previous innovation actions. Such examples include [8], [13]:

- the Poverty III program, run from 1989 to 1994 which included 29 model projects targeting lessfavored areas. Many organizations that were to become pillars of local development benefited from their first EU funding under the Poverty III program;

- the Community's economic development priorities of Objectives 1 and 2 in UK programs between 1994 and 2006 focused mainly on "bottom-up" local strategies for activating the labor market. They have been fully implemented through Merseyside 'Pathways to Integration' measures in the Objective 1 programs as well as the Objective 2 program implemented in Strathclyde;

- Community initiatives under the ESF (NOW, YOUTHSTART and ORIZONT 1994-1999) had a strong local component, as did several EQUAL themes (2000-2006), including those on the social economy and enterprise creation. The innovation principle promoted by the EQUAL initiative has favored the adoption of a local approach to innovative social innovation in Europe and has led to the creation of the slogan of the EQUAL Final Conference on „Free Movement of Good Ideas”

- The local social capital and new sources of employment initiatives, both on innovative actions and leading to experiments on new services, micro-projects and new financial instruments;

- A number of 89 territorial employment agreements/pacts were funded through the ESF technical assistance, the ERDF and the EAGGF (European Agricultural Guidance and Guarantee Fund) in the late 1990s. While most of the pacts related to policy alignment at higher territorial levels, about a third of them targeted a specific local approach (see, for example, the four Irish pacts in Limerick, Westmeath, Dundalk and Drogheda and Dublin) and have developed new approaches to correlating local demand and supply of jobs, including socially active businesses in the field of occupational insertion. The pacts continue in certain areas of Germany (eg in Berlin) and Austria (co-funded by the ESF) and have also been integrated into ESF programs in Hungary, Italy and Spain;

- The Progress Program (2007-2013) has funded Local Action Plans for Social Inclusion. Some social experiments under the Progress program have generated interesting results relevant to local development.

In the period 2007-2013, the lack of Community initiatives, combined with mixed results for inclusion in the overall policies of EQUAL, has led to a decline in the approaches to local development organized within the ESF. In spite of this, at local level, there is still a vibrant and opportunity-oriented culture of funding applications for ESF support. Many project initiators have made themselves known by participating in previous local development experiments. [11] 
The most important component of CLLDs are local action groups. Local Action Groups should be made up of representatives of the local socio-economic interests of public and private sectors such as entrepreneurs and their associations, local authorities, neighborhood associations or rural associations, groups of citizens (such as minorities, elderly citizens, women / men, young people, entrepreneurs, etc.), community and voluntary organizations etc. These LAGs are set up so that no partner or interest group is the majority ("maximum 49\%" rule), the civil society and private sector partners having to hold at least $50 \%$ of the decision-making power, so as to ensure a process of dialogue and not a simple consultation of the minority partners. It should be noted that the Commission's stated aim is to encourage the involvement of local communities in identifying solutions to specific problems and challenges rather than delegating tasks to local authorities.

The importance of community involvement was demonstrated by the success of the CLLD, supported by the LEADER approach, demonstrated through the existence of more than 2,300 local action groups active across the EU with a total real funding of $€ 5.5$ billion ( $6 \%$ of EAFRD funds).

The LEADER approach is the basis of the Commission's new initiative on CLLD and the mandatory reservation of 5\% of each Member State's EAFRD resources is maintained in the period 2014-2020, while the new legal framework will in turn greatly enhance the integrated approach. [9]

\section{Local Action Groups in several European countries}

In Finland, local authorities have a very strong role in providing local services, and even the smallest of them can have tax collection rights and employ hundreds of people. For the local action groups not to become an annex of municipalities, the Finnish management authority has set a very strict set of conditions for local action groups. They must be independent, non-profit organizations and all local actors must be able to become members. The average number of members is about one hundred. Members directly elect the board of directors, which must be made up of three equal parts: the public sector, the private sector and representatives of civil society (the rule of the third). Members of the Board may remain in office for a maximum of six years and must sign a declaration of their own interests.

The FEP Axis 4 implementation system in Finland provides an example of a centralized model. Local fisheries action groups encourage and select projects but final approval and payments are made through the regional offices of the intermediary body (ELY centers) to which program management responsibility has been delegated. The centers receive funding applications for the projects selected by the local fisheries action groups in their region and check eligibility before formal approval of projects. Once a project is approved, the ELY center will control implementation and make payments directly to the beneficiary. The Center is also responsible for reporting to the Managing Authority on approved projects, payments made and evaluation. The Finnish fisheries action groups use existing organizations, in some cases LEADER groups, as legal entities. They focus on the following tasks: developing a local development strategy, animation and support for project development, informal verification of application forms; project selection and reporting on group activities. Due to the proximity and trust between ELY centers and local fisheries action groups, projects can be approved within six weeks of being submitted to a local fisheries action group, sometimes even earlier.

In the Aragon region of Spain, the 20 LEADER local action groups directly approve local projects (sign the grant agreement) and pay the project initiators' grant when the project is completed. The regional management authority pays in advance $9 \%$ of the public budget of the local action group at the beginning of the period, if the group provides a bank guarantee. Initially, the partnership used to send four endorsements of approved and prepaid projects each year, and the amount was to be reimbursed by the regional government within two to three months. Such a procedure avoids liquidity problems. However, due to the impact of the economic crisis, the number of certifications was reduced to two and the time needed for groups to receive reimbursements increased, leading to increased pressure on cash flow. Local partnerships insist that this system significantly strengthens their status in the eyes of local stakeholders and allows them to respond to the needs of the project promoters with greater flexibility and speed. Local partnerships have explicitly called for continued application of the same method in the forthcoming period.

In Estonia, the process of setting up and selecting local action groups in the fisheries sector was supported by a training program for new one-year partnerships and a series of conferences. The program was organized by the Ministry of Agriculture, in cooperation with the national network support unit, the Pärnu University in Tartu and the training center in Tõru. The training plan was designed on the basis of three different target groups (fishermen and fisheries companies, representatives of local government, nonprofit associations) and had four main objectives: supporting the creation of eight local action groups in the fisheries sector, training leaders of local fisheries action groups that could launch the group's activities, development of cooperation between members of the local fisheries action group and the ability of groups to function as educational organizations, as well as the provision of know-how to members of local action groups in the area of fisheries in order to develop strategies for their areas of origin. The program included seminars on the legal framework of Axis 4, as well as training courses on how to create a partnership within a local action group and addressing the local development strategy and action plan. The program has also 
envisaged the stregthening of the capacity as regards project management, communication and procurement, and was accompanied by a comprehensive handbook.

Program costs amounted to almost $€ 100,000$ and were paid out of the national budget with technical assistance from the FEP. Local action groups were pre-selected using a simplified call for expressions of interest and received around $€ 70,000$ to support a local process of partnership consolidation and development of the development strategy of the area, which took place in parallel with capacity consolidation at national level. The allocated amount covered, for example, costs for studies, dissemination of information, meetings and specialized assistance. Following the priority given by Estonia to capacity consolidation/building, it was one of the first countries in Europe (at the beginning of 2010) where local fisheries action groups were able to support local projects.

In Sweden, the cooperation budget was allocated to the 63 local action groups that can select cooperation projects based on the same procedure as for other projects within their strategy. Up to $25 \%$ of the cooperation budget can be used for the preparation stages for cooperation.

In Poland, local action groups involved in cooperative actions are submitting a request from the regional intermediary body in an ongoing call for proposals (open until 30 June 2013 for preparatory work and up to 31 December 2013 for full projects) and the intermediary body must approve it within approximately two months since submission.

In Romania there are currently 239 LAGs and it is expected that their number will increase for the new NRDP 2014-2020. In the period 2007-2013, each Local Action Group had a project launching budget of $2,850,000$ euros from which they launched funding lines. The public financial support previously available was about 370 million euros. For the 2014-2020 period, funds for LAGs have almost doubled, so that if on the old program the LAGs received funding of nearly EUR 400 million ,for the 2014-2020 NRDP the allocation amounts to approximately 700 millions of euros.

\section{Conclusions}

Local development is one of the major operational instruments of EU cohesion policy which can provide new opportunities for the remotest areas and groups. The economic and financial crisis, the recovery plan and Europe 2020 put a strong pressure to rethink the approach to local development and yet, in the Member States of the European Union, the regions have different experiences.

Economic and demographic changes have highlighted the diversification and modification of local development models. Thus, in managing the change and restructuring of the territories there have been changes from the top-down policies of the instruments used by the national administrations to the local strategies and plans based on areas.

The area-based economic development stimulated by the local actions of endogenous development is a consecrated model of local development that targets both urban and rural areas. In addition, the support from new regional development councils or agencies and the national support programs have called for increasing involvement of local authorities and community actors in the development of their areas and, consequently, the rural and urban economy tends to integrate many concepts and instruments of local economic development. [4] [13]

The regions in each member state of the U.E. must have an axis dedicated to local development within all its regional development programs, able to focus, on the one hand, on urban economic development, local economic development of small and medium-sized cities, and, on the other, on rural development and harmonization of rural-urban relationships.

Local development strategies should be defined by the local groups, but the main problems and the designation of the areas should be predetermined at European or national level. Since regions and groups do not have the same capacity for development, the support of the U.E. must be focused on ensuring the sustainability of local initiatives and involve measures related to strategy (for example, SMEs, quality of life, training of the unemployed) and on capacity of building, skills of application and implementation of measures (for example, information, training of the personnel involved in the preparation and implementation of the local development strategy).

\section{References}

1. Acțiuni de dezvoltare locală sub responsabilitatea comunității, november 2012, Comisia Europeană;

2. Barna, B., Politica regională și dezvoltarea teritoriului, Fundația Diaspora, Timișoara, 2003;

3. Local development in cohesion policy CEMR, Bruxelles, 2010;

4. Barca, F., An Agenda for a Reformed Cohesion Policy: A Place-based Approach to Meeting European Union Challenges and Expectations, Bruxelles, 2014;

5. CEMR reponse to the cohesion policy 2014-2020; 
6. Community Led Local Development ECO/366, septembrie 2014, Bruxelles, European Economic and Social Committe;

7. Cohesion Policy 2014-2020, Towards a newpartnership and territorial approach, octombrie 2013, Council of European Municipalities and Regions;

8. Dezvoltarea locală plasată sub responsabilitatea comunităţii, Politica de coeziune 2014-2020;

9. European Commision Guidance on Community-Led Local Development for local actors - project examples;

10. New territorial instruments on cohesion policy: CLLD and ITI, 2014-2020;

11. Orientări privind dezvoltarea locală pasată sub responsabilitatea comunității pentru actorii locali, august 2014, Comisia Europeană;

12. Petrescu, C., coord., Economia socială în contextul dezvoltării locale, Institutul de cercetare a calității vieții, Editura Polirom, Iași, 2013;

13. www.ec.europa.eu;

14. www.ccre.org;

15. www.urban-intergroup.eu 